\title{
Time effect on the fractionation of heavy metals in soils
}

\author{
Anxiang Lu, Shuzhen Zhang*, Xiao-quan Shan \\ Key Laboratory of Environmental Chemistry and Ecotoxicology, Research Center for Eco-Environmental Sciences, \\ Chinese Academy of Sciences, P.O. Box 2871, 100085, China
}

Received 19 December 2003; received in revised form 6 July 2004; accepted 26 August 2004

Available online 25 September 2004

\begin{abstract}
Time effect on the fractionation of $\mathrm{Cu}, \mathrm{Zn}, \mathrm{Pb}$, and $\mathrm{Cd}$ in three typical Chinese soils was investigated. A total of $500 \mathrm{mg}$ $\mathrm{kg}^{-1}$ of $\mathrm{Cu}, \mathrm{Zn}, \mathrm{Pb}$ and $2.5 \mathrm{mg} \mathrm{kg}^{-1}$ of $\mathrm{Cd}$ were added to soils as nitrates. Metals in the incubated soils were fractionated termly from $3 \mathrm{~h}$ to 8 weeks by the sequential extraction procedure, in which the metal fractions were experimentally defined as exchangeable, carbonate-, Fe-Mn oxide-, organic matter-bound and residual fractions. Results showed that the changes of $\mathrm{Cu}, \mathrm{Pb}$ and $\mathrm{Zn}$ in fraction distribution were biphasic by an initial rapid step followed by a slow one. Metals in exchangeable fraction were increased in the first $3 \mathrm{~h}$, and then decreased, such decreases could be simulated by a diffusion equation and the decrease rate followed the order $\mathrm{Pb}>\mathrm{Cu}>\mathrm{Zn} \gg \mathrm{Cd}$. Metals bound to $\mathrm{Fe}-\mathrm{Mn}$ oxides and organic matter increased consistently in the 8-week incubation. There were almost no changes for the metals in the residual fraction. After 3-h incubation most of $\mathrm{Cd}$ added to soils presented in the exchangeable fraction. The content of $\mathrm{Cd}$ in each fraction changed slightly in the 8-week incubation. Soil pH played an important role in metal fraction distribution patterns. Jiangxi soil, with low soil $\mathrm{pH}$, tended to keep more metals added in exchangeable fraction and the changes of metals in each fraction were not as remarkable as in other two soils. High organic matter content resulted in the increased organic matter-bound fraction.

(C) 2004 Elsevier B.V. All rights reserved.
\end{abstract}

Keywords: Time effect; Heavy metals; Fractionation; Soil

\section{Introduction}

Soil contamination with anthropogenic heavy metals, which mainly comes from industrial activity, atmospheric deposition and land application of sewage sludge, has received much attention in

* Corresponding author. Tel.: +86 10 62849329; fax: +8610 62923563.

E-mail address: szzhang@mail.rcees.ac.cn (S. Zhang). recent years. The anthropogenic heavy metals are believed to be easily accumulated in the topsoil (Samsoe-Petersen et al., 2002; Baker, 1990), resulting in potential problems such as toxicity to plants and animals (Ma et al., 2002; Berti and Jacobs, 1996), accumulation in food chain, perturbation of the ecosystem and adverse health effects (Forstner, 1995; Stalikas et al., 1997).

Residence time directly relates to the bioavailability of heavy metals in soils (Pedersen et al., 
2000; Joner and Leyval, 2001; Alexander, 2000). Generally bioavailability of heavy metals decreases with increasing residence time (McLaughlin, 2001). Such time effect is ascribed to the reactions between metal ions and soils, which mainly include complexation, adsorption, and precipitation of metal ions in the soil particle surface or diffusion into the mesopores and micropores of soil. Although it is often assumed that residence time effect reduced metal mobility and bioavailability, only a few works have been carried out to investigate whether and how time effect influence the metal chemical forms and/or metal fractions in soils (Ma and Uren, 1998; Lim et al., 2002; Bataillard et al., 2003; Davies et al., 2003).

Total elemental contents provide little information on the mobility and bioavailability of the elements of interest. The mobility and bioavailability of heavy metals depend heavily on their physical and chemical forms. Sequential extraction, although operationally defined, can give information about the association of heavy metals with geochemical phases of soil, hence helps to reveal the distribution of heavy metals in fractions and to assess the mobility and toxicity of metals in soils (Tessier et al., 1979; Quevauiller et al., 1993, Ahnstrom and Parker, 1999). Among numerous sequential extraction methods, the method proposed by Tessier et al. (1979) was most widely used. According to this protocol, metals in soil were fractionated into exchangeable, carbonate-, Fe-Mn oxide-, organic matter-bound and residue fractions. Generally, exchangeable form was considered readily mobile and easily bioavailable, while residual form was considered to incorporate into crystalline lattice of soil minerals and appeared to be the most inactive. The carbonate-, Fe-Mn oxide-, and organic matterbound fractions could be considered relatively active depending on the actual physical and chemical properties of soil.

To fully understand time effect on bioavailability of anthropogenic heavy metals, detailed information is needed on the fractionation of metals after different residence time. The objective of this study was to investigate time effect on the fractionation of $\mathrm{Cu}, \mathrm{Pb}, \mathrm{Zn}$ and $\mathrm{Cd}$ added in soils. Differences of the fractionation among the metals and soils and the possible mechanism were discussed.

\section{Materials and methods}

\subsection{Soil samples}

Three topsoil samples $(0-20 \mathrm{~cm})$ were collected from Beijing, Jiangxi and Heilongjiang Provinces, China. Soil samples were air-dried and passed through a $2.0 \mathrm{~mm}$ sieve, homogenized and stored at $4{ }^{\circ} \mathrm{C}$ until use. Soil $\mathrm{pH}$ was measured with the soil to water ratio of 1:1 (w/v) (Hendershot et al., 1993a), organic matter (OM) was measured by $\mathrm{K}_{2} \mathrm{Cr}_{2} \mathrm{O}_{7}$ digestion method (Nelson and Sommers, 1996), cation exchange capacity (CEC) was determined by using a $0.1 \mathrm{~mol}$ $1^{-1} \mathrm{BaCl}_{2}$ displacement method (Hendershot et al., 1993b), the particle size was analyzed by the hydrometer method (Sheldrick and Wang, 1993). Crystal and amorphous Fe oxides were determined by the oxalate-ascorbic acid extraction and ammonium oxalate extraction methods, respectively (Ross and Wang, 1993). These properties are presented in Table 1.

\subsection{Incubation}

An incubation experiment was conducted with 500 $\mathrm{g}$ of each soil in plastic pot. Heavy metals $\mathrm{Cu}, \mathrm{Zn}, \mathrm{Pb}$ and $\mathrm{Cd}$ were added as nitrate salts $\mathrm{Cu}\left(\mathrm{NO}_{3}\right)_{2} \cdot 3 \mathrm{H}_{2} \mathrm{O}$, $\mathrm{Zn}\left(\mathrm{NO}_{3}\right)_{2} \cdot 6 \mathrm{H}_{2} \mathrm{O}, \mathrm{Pb}\left(\mathrm{NO}_{3}\right)_{2}$ and $\left.\mathrm{Cd}\left(\mathrm{NO}_{3}\right)_{2} \cdot 4 \mathrm{H}_{2} \mathrm{O}\right)$ in aqueous solution and then mixed with soils thoroughly. The amounts of metals added to soils were 500 $\mathrm{mg} \mathrm{kg}{ }^{-1}$ of $\mathrm{Cu}, \mathrm{Zn}$ and $\mathrm{Pb}$, and $2.5 \mathrm{mg} \mathrm{kg}^{-1}$ of $\mathrm{Cd}$

Table 1

Selected properties of tested soils

\begin{tabular}{lccc}
\hline Item & Beijing & Jiangxi & Heilongjiang \\
\hline $\mathrm{pH}$ & 6.90 & 4.56 & 7.35 \\
$\mathrm{OM}(\%)$ & 4.35 & 1.53 & 6.40 \\
$\mathrm{CEC}(\mathrm{c} \mathrm{mol} \mathrm{kg}$ & -1 \\
Particle-size distribution (\%) & 15.7 & 14.2 & 26.3 \\
$\quad$ Clay & 10.8 & 42.4 & 27.4 \\
Silt & 51.6 & 18.7 & 62.8 \\
Sand & 37.6 & 19.5 & 9.8 \\
Oxide of Fe $\left(\mathrm{g} \mathrm{kg}^{-1}\right)$ & & & \\
Crystal & 8.87 & 35.2 & 15.0 \\
Amorphous & 3.22 & 7.24 & 4.03 \\
Concentration of metals (mg kg & & & \\
Cu & 21.6 & 22.8 & 9.16 \\
$\mathrm{Zn}$ & 33.6 & 31.2 & 28.9 \\
$\mathrm{~Pb}$ & 33.4 & 19.5 & 33.0 \\
$\mathrm{Cd}$ & 0.51 & 0.32 & 0.44 \\
\hline
\end{tabular}


(metal/soil), respectively. Samsoe-Petersen et al. (2002) investigated 75 different heavy metal contaminated soils and ranged them into three levels: uncontaminated, medium and heavily contaminated. According to his classification and the level defined by Chinese Environmental Protection Agency (Chinese EPA, 1995), the selected concentrations in this study represented the heavily contaminated soils. Extra pots without addition of heavy metals were simultaneously prepared as control. Soil samples were maintained at about $70 \%$ of water holding capacity by periodically weighing the pots and adjusting the weight by addition of distilled water. The soils were incubated for 3 h, 1, 3 days, 1, 2, 3, 4, 6 and 8 weeks, each treatment was repeated in duplicate. After incubation, metals in treated and control soils were fractionated by the sequential extraction procedure of Tessier et al. (1979) in triplicate. The chemical reagents, extraction conditions and corresponding fractions are listed in Table 2. Extractions were conducted in $50 \mathrm{ml}$ polypropylene centrifuge tubes. Between each successive extraction, the supernatant was centrifuged at $6000 \mathrm{rpm}$ for $15 \mathrm{~min}$, and filtered. As a check for the reliability of sequential extraction procedure, ratios of the sum of the metal concentration in individual fractions to the total metal concentration in soils were calculated and were from $81.0 \%$ to $101.2 \%$. Lower ratios were considered as the cumulative losses of each extraction procedures (Pueyo et al., 2003).

Table 2

Sequential extraction procedure and the corresponding fractions

\begin{tabular}{|c|c|c|}
\hline Step & Fraction & Extraction procedure \\
\hline 1 & $\begin{array}{l}\text { Exchangeable } \\
(\mathrm{EXC})\end{array}$ & $\begin{array}{l}1 \mathrm{~g} \text { of soil sample, } 8 \mathrm{ml} 1 \mathrm{~mol}^{-1} \\
\mathrm{MgCl}_{2}, \mathrm{pH} 7 \text {, shake } 1 \mathrm{~h} \text {, room } \\
\text { temperature }\end{array}$ \\
\hline 2 & $\begin{array}{l}\text { Bound to } \\
\text { carbonate } \\
\text { (CA) }\end{array}$ & $\begin{array}{l}8 \mathrm{ml} 1 \mathrm{~mol} \mathrm{l}^{-1} \mathrm{CH}_{3} \mathrm{COONa} \text {, } \\
\text { adjusted } \mathrm{pH} \text { to } 5.0 \text { with } \mathrm{CH}_{3} \mathrm{COOH} \text {, } \\
\text { shake } 5 \mathrm{~h} \text {, room temperature }\end{array}$ \\
\hline 3 & $\begin{array}{l}\text { Bound to } \mathrm{Fe}-\mathrm{Mn} \\
\text { oxides (Fe-Mn) }\end{array}$ & $\begin{array}{l}20 \mathrm{ml} 0.04 \mathrm{~mol} \mathrm{l}^{-1} \mathrm{NH}_{2} \mathrm{OH} \cdot \mathrm{HCl} \text { in } \\
25 \% \mathrm{CH}_{3} \mathrm{COOH}, \mathrm{pH} 2.0 \text {, water bath, } \\
96{ }^{\circ} \mathrm{C}, 6 \mathrm{~h} \text {, occasional shaking }\end{array}$ \\
\hline 4 & $\begin{array}{l}\text { Bound to organic } \\
\text { matter }(\mathrm{OM})\end{array}$ & $\begin{array}{l}3 \mathrm{ml} 0.02 \mathrm{~mol} \mathrm{l}^{-1} \mathrm{HNO}_{3}, 30 \% \mathrm{H}_{2} \mathrm{O}_{2} \\
\text { (adjusted to } \mathrm{pH} 2.0 \text { ), water bath, } 85{ }^{\circ} \mathrm{C} \text {, } \\
5 \mathrm{~h}, 3.2 \mathrm{~mol} \mathrm{l}^{-1} \mathrm{CH}_{3} \mathrm{COONH}_{4} \text { in } 20 \% \\
\text { (v/v) } \mathrm{HNO}_{3} \text {, shake } 30 \mathrm{~min}\end{array}$ \\
\hline 5 & Residual (RES) & $\begin{array}{l}3 \mathrm{ml} \mathrm{HNO}_{3}+\mathrm{HClO}_{4}+\mathrm{HF} \text { under high } \\
\text { pressure, } 170{ }^{\circ} \mathrm{C}\end{array}$ \\
\hline
\end{tabular}

\subsection{Metal determination}

Metal concentrations in soil fractions were determined by inductively coupled plasma-mass spectrometry (ICP-MS; VG PlasnaQuard 3, Fisons Instruments, UK) under optimized operating conditions. The total metal concentrations in soils were determined after digestion with $\mathrm{HNO}_{3}-\mathrm{HF}-\mathrm{HClO}_{4}$ (1:1:1) mixture under high pressure conditions. The digestion procedure of soil samples and optimization of ICP-MS were detailed in our previous study (Zhang and Shan, 1997).

\section{Results and discussion}

\subsection{Changes of heavy metal concentrations in differ- ent fractions}

Tables 3, 4 and 5 show the distribution of heavy metals $\mathrm{Cu}, \mathrm{Zn}, \mathrm{Pb}$ and $\mathrm{Cd}$ in the five fractions: exchangeable (EXC), carbonate (CA), Fe-Mn oxides $(\mathrm{Fe}-\mathrm{Mn})$, organic matter $(\mathrm{OM})$ and residual (RES) fractions in the control and the spiked soils incubated for $3 \mathrm{~h}, 3$ days and 8 weeks. Other values were excluded here otherwise the tables would be too big. In the control soils, the background $\mathrm{Cu}, \mathrm{Zn}, \mathrm{Pb}$ and $\mathrm{Cd}$ in each fraction were generally in the order residual $>$ exchangeable $>\mathrm{Fe}-\mathrm{Mn}$ oxides $>$ organic matter $>$ carbonate fraction. It was observed that after $3 \mathrm{~h}$ of incubation metals in exchangeable fraction were predominant in the spiked soils and the increases in the other fractions were also observed except in residual fraction. It may indicate that a fast process of metal distribution among the fractions occurred during the first 3 -h incubation. From $3 \mathrm{~h}$ to 8 weeks, metals decreased in exchangeable fraction and increased in $\mathrm{Fe}-\mathrm{Mn}$ oxides and in organic matter bound fractions. The redistribution process happened from $3 \mathrm{~h}$ to 8 weeks is much slower comparing with that in hours. At the end of 8-week incubation, the percentages of $\mathrm{Cu}, \mathrm{Zn}, \mathrm{Pb}$ and $\mathrm{Cd}$ in exchangeable fraction were still very high, which is consistent with the results obtained by Lim et al. (2002), who studied the adsorption of $\mathrm{Pb}$ and $\mathrm{Cd}$ on soil clays incubated for over 65 days by using sequential extraction. This observation was possibly due to the slow transformation of metals from loosely bound fractions such as exchangeable fraction to strongly bound 
Table 3

Concentration of $\mathrm{Cu}, \mathrm{Zn}, \mathrm{Pb}$ and $\mathrm{Cd}$ in each fraction in Beijing soil $\left(\mathrm{mg} \mathrm{kg}^{-1}\right)$

\begin{tabular}{|c|c|c|c|c|c|c|c|c|}
\hline Element & Time & $\mathrm{EXC}$ & $\mathrm{CA}$ & $\mathrm{Fe}-\mathrm{Mn}$ & $\mathrm{OM}$ & RES & Sum & Total \\
\hline \multirow[t]{4}{*}{$\mathrm{Cu}$} & Control & 5.66 & 0.273 & 3.13 & 1.03 & 10.7 & 20.8 & 21.6 \\
\hline & $3 \mathrm{~h}$ & 260 & 153 & 33.6 & 54.0 & 11.4 & 512 & 530 \\
\hline & 3 days & 248 & 139 & 44.2 & 67.5 & 10.3 & 509 & 526 \\
\hline & 8 weeks & 160 & 118 & 126 & 91.5 & 10.3 & 506 & 522 \\
\hline \multirow[t]{4}{*}{$\mathrm{Zn}$} & Control & 10.7 & 1.02 & 7.45 & 1.95 & 12.1 & 33.2 & 33.6 \\
\hline & $3 \mathrm{~h}$ & 430 & 47.3 & 21.3 & 1.82 & 14.2 & 515 & 539 \\
\hline & 3 days & 418 & 49.8 & 25.8 & 1.98 & 12.2 & 508 & 529 \\
\hline & 8 weeks & 343 & 70.0 & 65.0 & 3.43 & 13.2 & 495 & 526 \\
\hline \multirow[t]{4}{*}{$\mathrm{Pb}$} & Control & 8.39 & 0.551 & 3.35 & 4.41 & 15.1 & 31.8 & 33.4 \\
\hline & $3 \mathrm{~h}$ & 398 & 40.1 & 47.8 & 14.6 & 14.6 & 515 & 548 \\
\hline & 3 days & 379 & 42.4 & 59.5 & 26.0 & 15.2 & 522 & 567 \\
\hline & 8 weeks & 231 & 63.0 & 131 & 67.5 & 15.7 & 508 & 526 \\
\hline \multirow[t]{4}{*}{$\mathrm{Cd}$} & Control & 0.164 & 0.0236 & 0.0247 & 0.0453 & 0.221 & 0.479 & 0.509 \\
\hline & $3 \mathrm{~h}$ & 1.92 & 0.298 & 0.0655 & 0.0298 & 0.205 & 2.52 & 2.74 \\
\hline & 3 days & 1.88 & 0.283 & 0.114 & 0.0418 & 0.219 & 2.54 & 2.91 \\
\hline & 8 weeks & 1.80 & 0.268 & 0.141 & 0.0518 & 0.218 & 2.48 & 2.85 \\
\hline
\end{tabular}

fractions such as $\mathrm{Fe}-\mathrm{Mn}$ oxide and organic matterbound fractions in the conditions with high metal concentrations in spiked soils and low water contents in soils. No significant differences $(p<0.01)$ in the metal concentrations of the residual fraction were observed between the control and spiked soil samples. After 8-week incubation the added metals were unlikely to enter the crystalline lattice.

Fig. 1 shows the time-dependent changes of $\mathrm{Cu}$ concentration in each fraction. Incubation time affected the fraction distribution of $\mathrm{Cu}$ significantly. The newly added $\mathrm{Cu}$ existed mainly in the surface of soil particles as exchangeable fraction. After 3-h incubation, $\mathrm{Cu}$ in exchangeable fraction was 260, 360 and $332 \mathrm{mg} \mathrm{kg}^{-1}$ in Beijing, Jiangxi and Heilongjiang soils, respectively. When the incubation time was prolonged metal concentration of the exchangeable fraction decreased, especially for Beijing and Heilongjiang soils, more than $100 \mathrm{mg} \mathrm{kg}^{-1}$ exchangeable $\mathrm{Cu}$ was transformed into other fractions. But in Jiangxi soil, the decrease of $\mathrm{Cu}$ in exchangeable fraction was only by $26 \mathrm{mg} \mathrm{kg}^{-1}$. From the incubation time of 3 days to 8 weeks, the decreases of $\mathrm{Cu}$ in carbonate bound fraction were by $35.0,59.8$,

Table 4

Concentration of $\mathrm{Cu}, \mathrm{Zn}, \mathrm{Pb}$ and $\mathrm{Cd}$ in each fraction in Jiangxi soil $\left(\mathrm{mg} \mathrm{kg}^{-1}\right)$

\begin{tabular}{|c|c|c|c|c|c|c|c|c|}
\hline Element & Time & EXC & CA & $\mathrm{Fe}-\mathrm{Mn}$ & $\mathrm{OM}$ & RES & Sum & Total \\
\hline \multirow[t]{4}{*}{$\mathrm{Cu}$} & Control & 3.46 & 0.282 & 1.41 & 1.90 & 14.8 & 21.6 & 22.8 \\
\hline & $3 \mathrm{~h}$ & 360 & 109 & 37.2 & 11.4 & 15.7 & 533 & 554 \\
\hline & 3 days & 352 & 74.5 & 54.5 & 17.2 & 15.2 & 513 & 541 \\
\hline & 8 weeks & 334 & 49.2 & 78.5 & 20.1 & 15.5 & 497 & 543 \\
\hline \multirow[t]{4}{*}{$\mathrm{Zn}$} & Control & 4.55 & 0.345 & 3.65 & 0.623 & 20.4 & 29.6 & 31.2 \\
\hline & $3 \mathrm{~h}$ & 437 & 50.5 & 12.7 & 0.865 & 19.2 & 520 & 537 \\
\hline & 3 days & 428 & 38.8 & 18.8 & 1.42 & 18.9 & 506 & 512 \\
\hline & 8 weeks & 420 & 34.1 & 24.7 & 1.32 & 21.2 & 501 & 565 \\
\hline \multirow[t]{4}{*}{$\mathrm{Pb}$} & Control & 2.37 & 1.15 & 1.04 & 0.982 & 12.2 & 17.7 & 19.5 \\
\hline & $3 \mathrm{~h}$ & 389 & 27.0 & 25.9 & 22.5 & 11.9 & 476 & 503 \\
\hline & 3 days & 374 & 29.3 & 39.1 & 53.0 & 12.4 & 508 & 541 \\
\hline & 8 weeks & 353 & 26.4 & 44.2 & 69.5 & 12.6 & 506 & 534 \\
\hline \multirow[t]{4}{*}{$\mathrm{Cd}$} & Control & 0.0329 & 0.00638 & 0.0388 & 0.0283 & 0.185 & 0.291 & 0.317 \\
\hline & $3 \mathrm{~h}$ & 2.18 & 0.103 & 0.0493 & 0.0227 & 0.173 & 2.53 & 2.84 \\
\hline & 3 days & 2.16 & 0.138 & 0.0385 & 0.0247 & 0.176 & 2.54 & 2.79 \\
\hline & 8 weeks & 2.07 & 0.173 & 0.0393 & 0.0388 & 0.186 & 2.51 & 3.04 \\
\hline
\end{tabular}


Table 5

Concentration of $\mathrm{Cu}, \mathrm{Zn}, \mathrm{Pb}$ and $\mathrm{Cd}$ in each fraction in Heilongjiang soil $\left(\mathrm{mg} \mathrm{kg}^{-1}\right)$

\begin{tabular}{|c|c|c|c|c|c|c|c|c|}
\hline Element & Time & EXC & $\mathrm{CA}$ & $\mathrm{Fe}-\mathrm{Mn}$ & $\mathrm{OM}$ & RES & Sum & Total \\
\hline \multirow[t]{4}{*}{$\mathrm{Cu}$} & Control & 3.61 & 0.118 & 0.122 & 0.604 & 4.82 & 9.28 & 9.16 \\
\hline & $3 \mathrm{~h}$ & 332 & 118 & 38.5 & 19.1 & 5.01 & 512 & 517 \\
\hline & 3 days & 281 & 92.5 & 68.2 & 57.3 & 5.34 & 504 & 528 \\
\hline & 8 weeks & 190 & 61.5 & 113 & 126 & 5.49 & 496 & 530 \\
\hline \multirow[t]{4}{*}{$\mathrm{Zn}$} & Control & 4.57 & 0.424 & 4.81 & 4.42 & 12.9 & 27.1 & 28.9 \\
\hline & $3 \mathrm{~h}$ & 422 & 30.6 & 20.4 & 1.39 & 13.4 & 488 & 526 \\
\hline & 3 days & 407 & 34.0 & 41.5 & 2.88 & 15.2 & 501 & 560 \\
\hline & 8 weeks & 348 & 55.1 & 76.5 & 6.70 & 11.8 & 498 & 558 \\
\hline \multirow[t]{4}{*}{$\mathrm{Pb}$} & Control & 2.12 & 3.17 & 3.84 & 5.96 & 15.4 & 30.5 & 33.0 \\
\hline & $3 \mathrm{~h}$ & 395 & 19.5 & 59.6 & 38.9 & 15.9 & 529 & 544 \\
\hline & 3 days & 321 & 25.2 & 87.5 & 57.5 & 15.7 & 507 & 522 \\
\hline & 8 weeks & 179 & 30.0 & 177 & 106 & 16.3 & 508 & 521 \\
\hline \multirow[t]{4}{*}{$\mathrm{Cd}$} & Control & 0.0962 & 0.0166 & 0.0638 & 0.0440 & 0.191 & 0.412 & 0.435 \\
\hline & $3 \mathrm{~h}$ & 2.01 & 0.254 & 0.0171 & 0.0168 & 0.181 & 2.48 & 2.83 \\
\hline & 3 days & 1.98 & 0.240 & 0.0875 & 0.0420 & 0.186 & 2.54 & 3.09 \\
\hline & 8 weeks & 1.94 & 0.206 & 0.140 & 0.0565 & 0.177 & 2.52 & 3.11 \\
\hline
\end{tabular}

and $56.5 \mathrm{mg} \mathrm{kg}^{-1}$ in Beijing, Jiangxi and Heilongjiang soils, respectively. The amounts of $\mathrm{Cu}$ bounded with $\mathrm{Fe}-\mathrm{Mn}$ oxides increased consistently with increasing incubation time. After 8 weeks of incubation the concentration of $\mathrm{Cu}$ in $\mathrm{Fe}-\mathrm{Mn}$ oxide-bound fraction reached $126,78.5$, and $113 \mathrm{mg} \mathrm{kg}^{-1}$ in
Beijing, Jiangxi and Heilongjiang soils, respectively. In organic matter fraction, $\mathrm{Cu}$ concentration increased by $37.5,8.7$, and $107 \mathrm{mg} \mathrm{kg}^{-1}$ in Beijing, Jiangxi, and Heilongjiang soils. The increase of $\mathrm{Cu}$ in organic matter fraction in Heilongiiang soil was much more than that in other two soils.
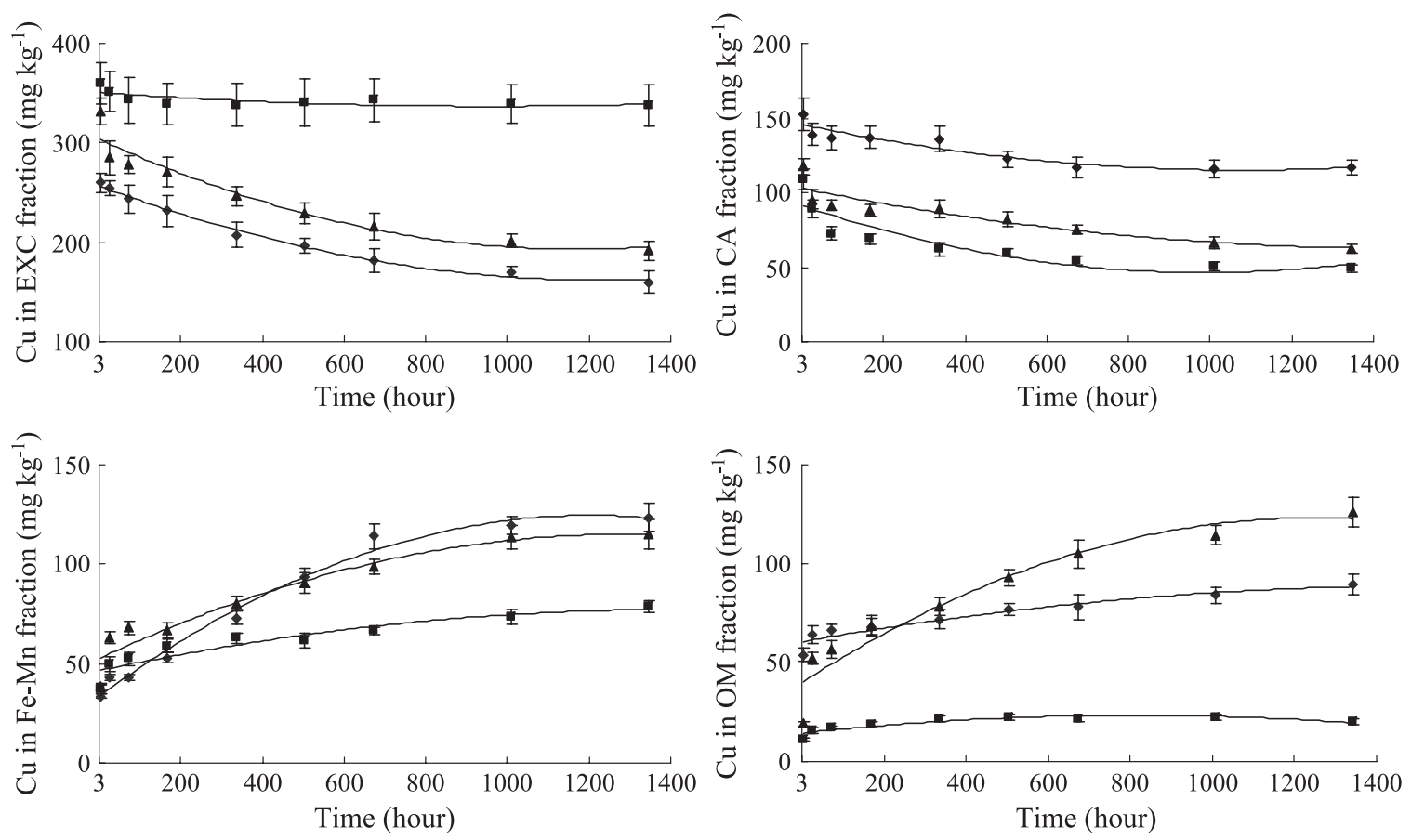

Fig. 1. Concentration of $\mathrm{Cu}$ in different fractions 
The changes of $\mathrm{Zn}$ in each fraction are shown in Fig. 2. After 3-h incubation, greater content of $\mathrm{Zn}$ was observed in exchangeable fraction than that of $\mathrm{Cu}$. From $3 \mathrm{~h}$ to 8 weeks, the concentration of $\mathrm{Zn}$ in exchangeable fraction deceased by 87 and $74 \mathrm{mg}$ $\mathrm{kg}^{-1}$ in Beijing and Heilongjiang soils, for Jiangxi soil the content of $\mathrm{Zn}$ in exchangeable fraction almost remained unchanged. Unlike the decrease of $\mathrm{Cu}$ in carbonate fraction, $\mathrm{Zn}$ in this fraction increased with increasing incubation time in Beijing and Heilongjiang soils by 22.7 and $24.4 \mathrm{mg} \mathrm{kg}^{-1}$ and there was $16.4 \mathrm{mg} \mathrm{kg}^{-1}$ decreased in Jiangxi soil. Zinc in Fe-Mn oxide fraction also increased by 43.7 and $56.1 \mathrm{mg} \mathrm{kg}^{-1}$ for Beijing and Heilongjiang soils. However, the increase was insignificant for Jiangxi soil.

Fig. 3 gives the change tendency of $\mathrm{Pb}$ in the soil fractions, which was similar to that of $\mathrm{Cu}$. From $3 \mathrm{~h}$ to 8 weeks, $\mathrm{Pb}$ in the exchangeable fraction decreased by 167,36 and $216 \mathrm{mg} \mathrm{kg}^{-1}$ in Beijing, Jiangxi and Heilongjiang soils, respectively. Changes of $\mathrm{Pb}$ in carbonate fraction were not consistent. Lead bound to $\mathrm{Fe}-\mathrm{Mn}$ oxide and organic matter had the similar change patterns and increased significantly in Beijing, Heilongjiang soils, but not in Jiangxi soil.

Distribution of $\mathrm{Cd}$ among the fractions was different from other three elements (Fig. 4). Most of $\mathrm{Cd}$ added to soils appeared in the exchangeable fraction after $3 \mathrm{~h}$ and the distribution patterns of $\mathrm{Cd}$ among each fraction had no significant change in the incubation time from $3 \mathrm{~h}$ to 8 weeks. After 8-week incubation, the exchangeable fraction remained the most dominant fraction in three soils. McGrath and Cegarra (1992) found that the concentration of $\mathrm{Cd}$ extracted with $0.1 \mathrm{~mol} \mathrm{l}^{-1} \mathrm{CaCl}_{2}$ was much higher than those of $\mathrm{Zn}, \mathrm{Cu}$ and $\mathrm{Pb}$ in the soil amended with sewage sludge. Naidu et al. (1994) reported that the exchangeable $\mathrm{Cd}$ was probably hydrated $\mathrm{Cd}^{2+}$ and adsorbed via out-sphere surface complexation, therefore, barricading the transformation from exchangeable fraction. The changes of $\mathrm{Cd}$ in carbonate, $\mathrm{Fe}-\mathrm{Mn}$ oxide and organic matte fractions were insignificant and the experimental variations might have masked the time-dependent transformation among the fractions.

During 8-week incubation, $\mathrm{Cu}, \mathrm{Zn}, \mathrm{Pb}$ in exchangeable fraction decreased and $\mathrm{Fe}-\mathrm{Mn}$ and organic
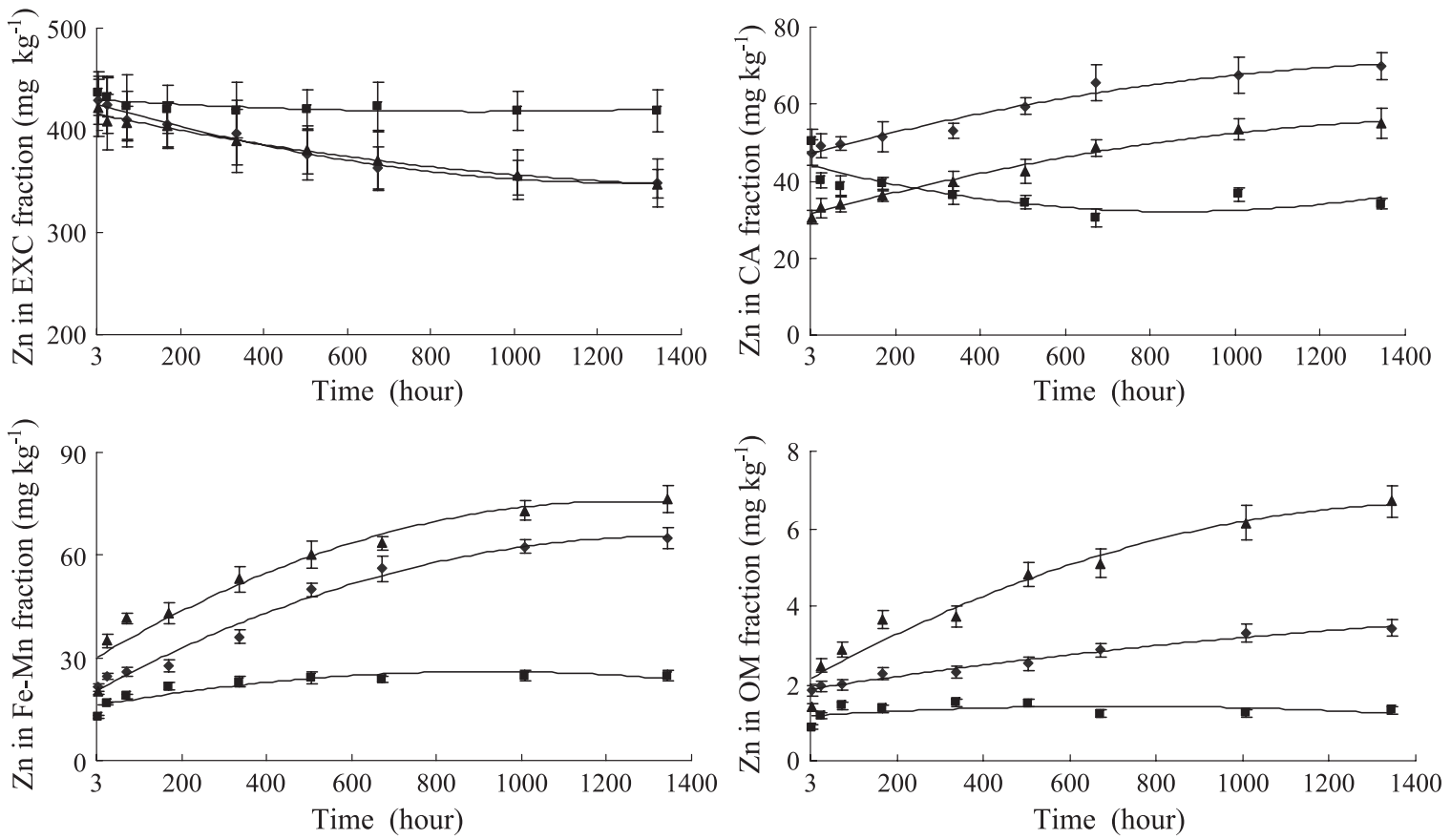

Fig. 2. Concentration of $\mathrm{Zn}$ in different fractions

Beijing soil;

Jiangxi soil;

Heilongjiang soil). 

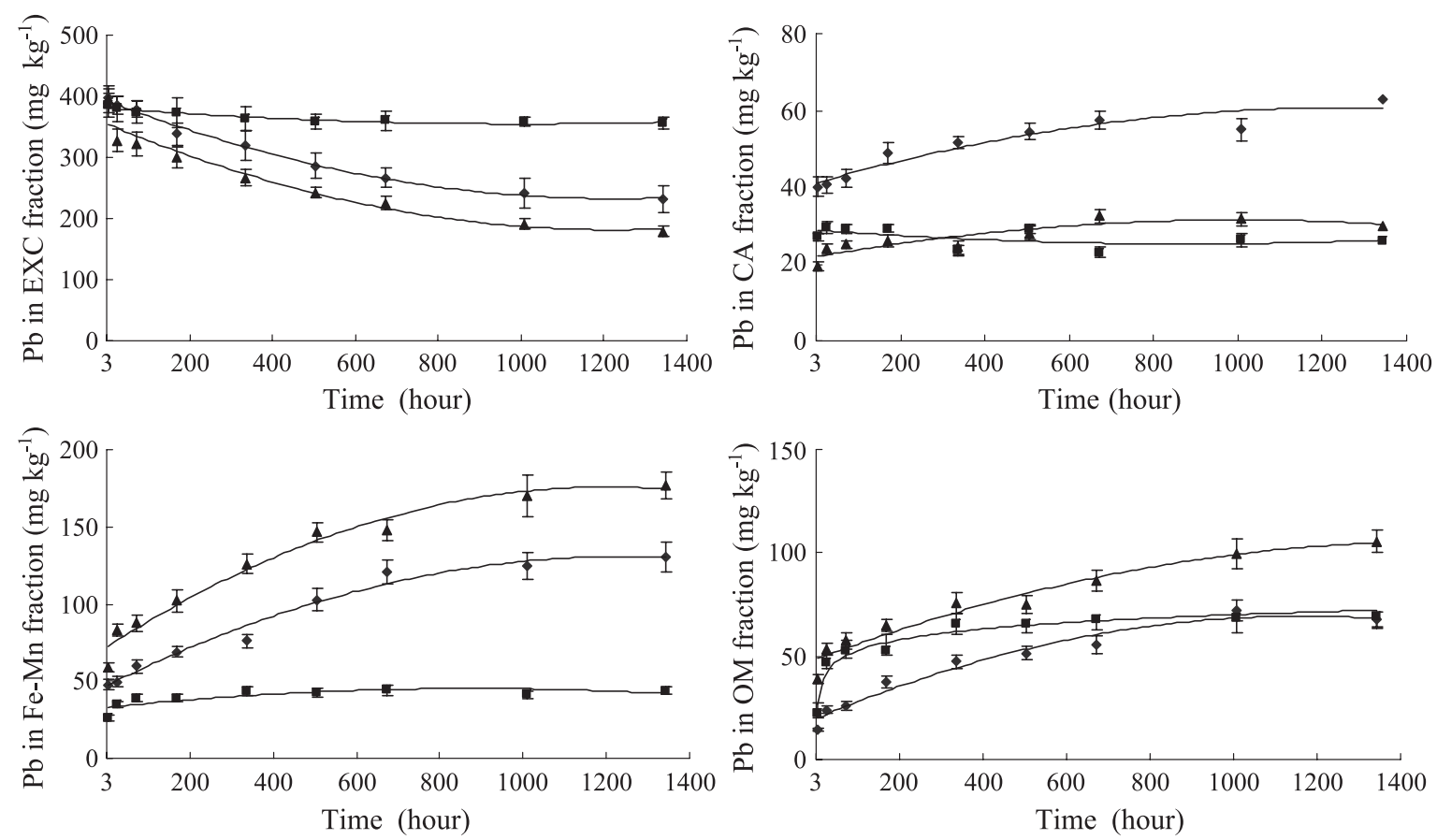

Fig. 3. Concentration of $\mathrm{Pb}$ in different fractions

Beijing soil; $\mathbf{\square}$ Jiangxi soil; $\boldsymbol{\Delta}$ Heilongjiang soil).
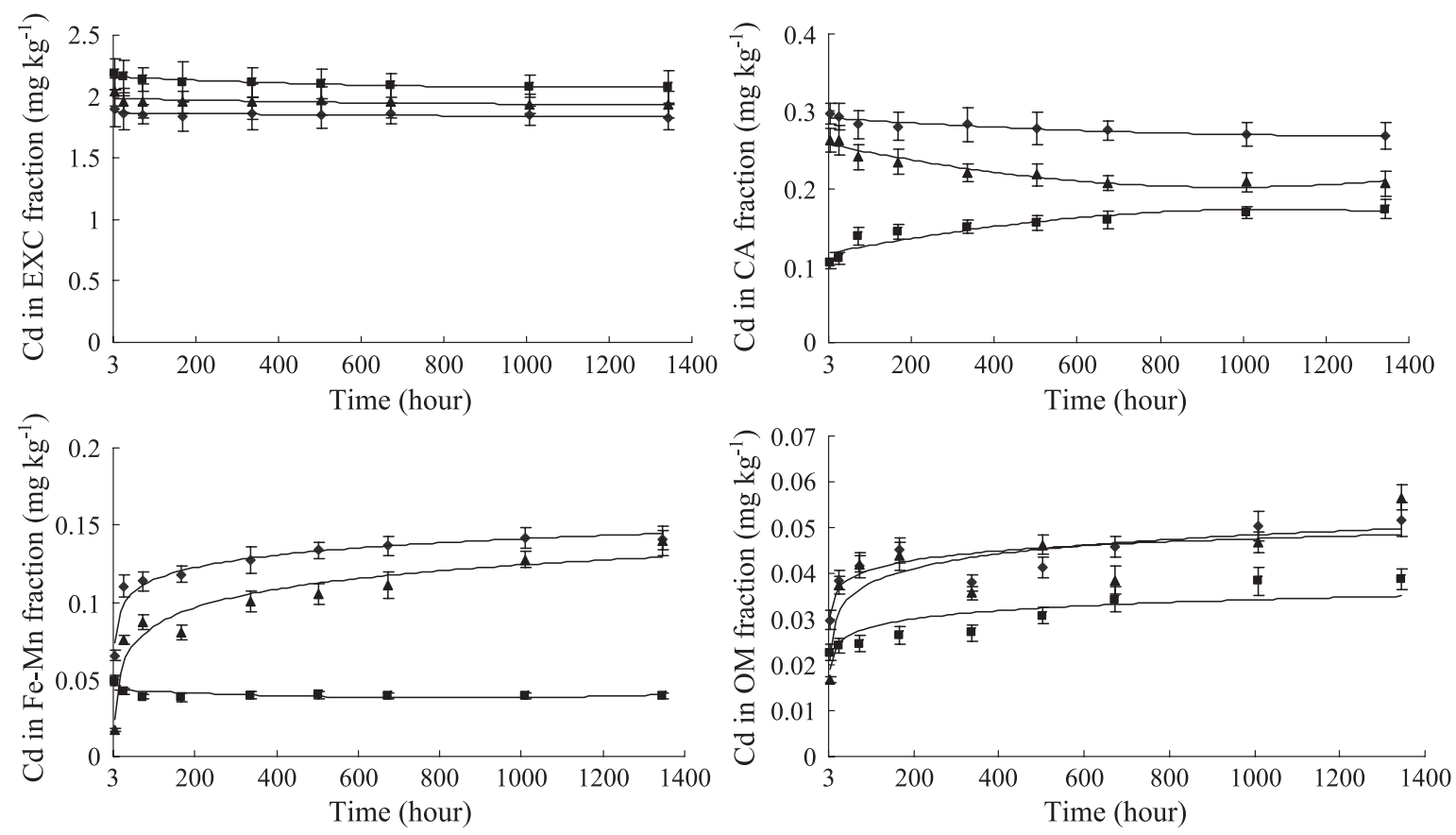

Fig. 4. Concentration of $\mathrm{Cd}$ in different fractions ( Beijing soil; $\boldsymbol{\nabla}$ Jiangxi soil; $\boldsymbol{\Delta}$ Heilongjiang soil). 
bound fractions increased, such changes for Cd was not as obvious as for $\mathrm{Cu}, \mathrm{Zn}$ and $\mathrm{Pb}$. Redistribution of the heavy metals among the fractions did not reach equilibrium in 8 weeks, slower changes among fractions were still observed.

\subsection{Comparison of the fractionations among metals and soils}

Most of the anthropogenic heavy metals were adsorbed on the soil surfaces as the exchangeable form rapidly and then slowly transformed into stable forms with time (McLaughlin, 2001). The decreases of heavy metals as exchangeable forms could be simulated in a linear relationship with time as the following equation:

$\log C_{\mathrm{m}}=A+B T$

Where $C_{\mathrm{m}}$ is the concentration of heavy metals in exchangeable fraction, $T$ is time, $A$ and $B$ are constants, which may have some relationship with the properties of soil and heavy metals. The coefficients were from 0.7713 to $0.9708(p<0.01)$, as illustrated in Fig. 5. This equation can be expressed in another way:

$C_{\mathrm{m}}=A \exp (B T)$

It is one of the solutions for the diffusion equation:

$\frac{\partial C}{\partial T}=D\left(\frac{\partial^{2} C}{\partial r^{2}}+\frac{2}{r} \frac{\partial C}{\partial r}\right)$

where $C$ is the concentration of metals, $T$ is contact time, $r$ is soil particle radius and $D$ is diffusion coefficient. This solution indicated that the decreases of the exchangeable metals were mainly attributed to the diffusive processes of metals, possibly through the mesopores and micropores of soil.

Among the metals investigated, $\mathrm{Pb}$ and $\mathrm{Cu}$ were easily transformed from the exchangeable fraction to more stable fractions during the incubation period than $\mathrm{Zn}$ and $\mathrm{Cd}$. If we defined the constant $\mathrm{B}$ in equation as the transformation rate, which were in the order $\mathrm{Pb}>\mathrm{Cu}>\mathrm{Zn} \gg \mathrm{Cd}$. By using goethite (Forbes et al., 1974) and organic matter (Carmen and Murray, 1999) as adsorbents to investigate the metal
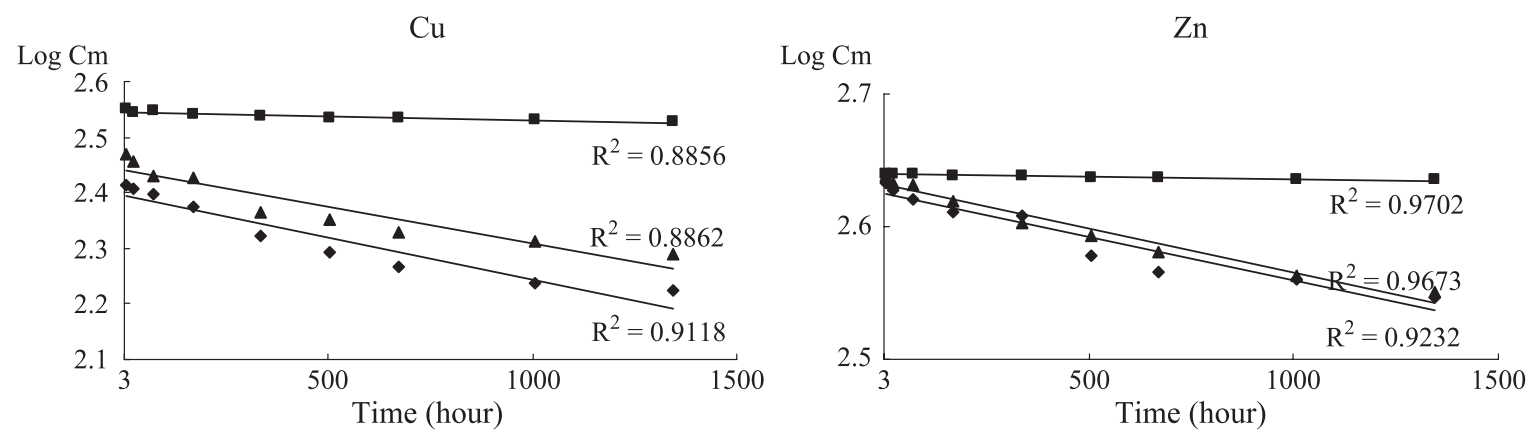

$\mathrm{Pb}$
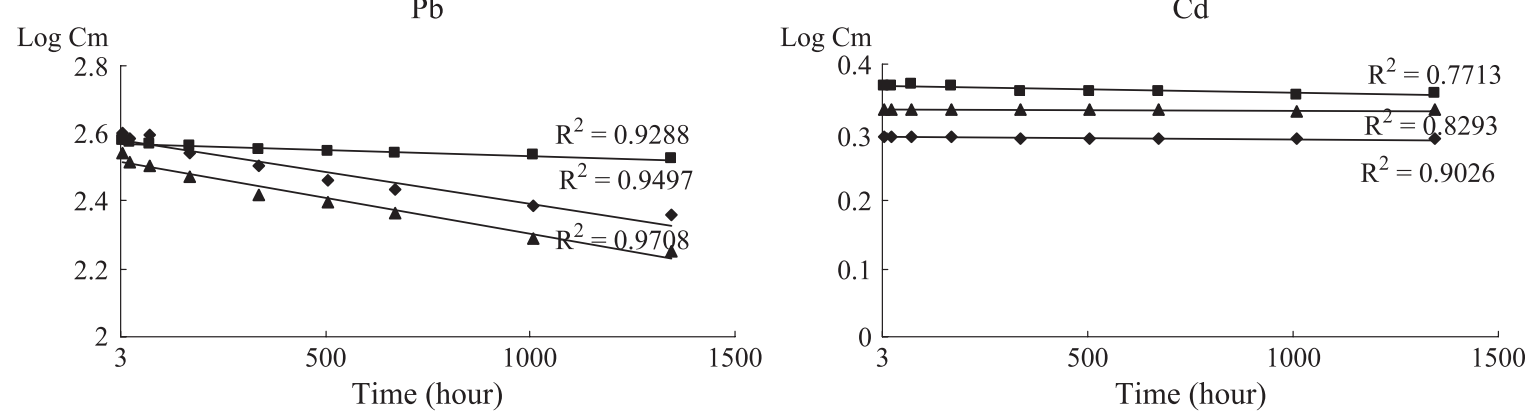

Fig. 5. Decreases of $\mathrm{Cu}, \mathrm{Zn}, \mathrm{Pb}$ and $\mathrm{Cd}$ in exchangeable fraction as a function of incubation time ( $\boldsymbol{B}$ Beijing soil; $\mathbf{\square}$ Jiangi soil; Heilongjiang soil). 
retention on soil components, the same order of metal affinity was obtained as the transformation rate in this work.

Only three soils were used in this experiment and therefore, correlation analysis between the fractionation and soil properties could not be conducted. However, remarkable differences in fraction distribution could be observed between Jiangxi and other two soils, for Jiangxi soil the changes of all the elements in fractions are not obvious in the test period. Among the soils, Jiangxi soil had the highest metal concentration in exchangeable fraction, and the decreases of the metals in exchangeable fraction were insignificant and the decreases in other fractions were also not as distinct as in other two soils. This phenomenon may contribute to the low soil $\mathrm{pH}$ of Jiangxi soil. The $\mathrm{pH}$ of Beijing and Heilongjiang soils are 6.90 and 7.35, whereas the $\mathrm{pH}$ of Jiangxi soil is 4.56. Acidic soil condition favors the metals added to soil as soluble in soil solution or weakly adsorbed on soil particle, and also restricts the metal ions to diffuse into the micropores of soil or complex with soil minerals or organic matter. Lim et al. (2002) investigated the changes of speciation of $\mathrm{Pb}$ and $\mathrm{Cd}$ in soil at various $\mathrm{pH}$ values with different time and found that the changes of $\mathrm{Pb}$ and $\mathrm{Cd}$ in exchangeable fraction were $\mathrm{pH}$-dependent. Generally, the change was small under acidic condition and larger decrease occurred at $\mathrm{pH} 7$. By monitoring the process of heavy metals on iron oxide $(\alpha-\mathrm{FeOOH})$, Carmen and Murray (2001) found that either adsorption or coprecipitation of heavy metals with ferrihydrite were $\mathrm{pH}$-dependent. They also found that the increasing $\mathrm{pH}$ and incubation time resulted in the increase of adsorption and coprecipitation of heavy metals.

Among the fractions, changes of heavy metals in the carbonate fraction were least and not of uniform in the incubation time from $3 \mathrm{~h}$ to 8 weeks. Soil organic matter has been recognized as a critical component in the retention of heavy metals in soils. The increase of organic matter in soil would help to reduce the metal ions from exchangeable sites and acidic conditions (Eillott et al., 1986; Weng et al., 2002). In this experiment, the contents of $\mathrm{OM}$ of three soils were in the order: Heilongjiang $>$ Beijing $>$ Jiangxi soil, the heavy metal concentrations in organic matters also followed this order. High content of OM can enhance the binding of metals to this fraction.

\section{Conclusion}

The fractionation data monitored during 8-week incubation revealed the distribution patterns of $\mathrm{Cu}$, $\mathrm{Zn}, \mathrm{Pb}$ and $\mathrm{Cd}$ in soils. The soluble metals added were transformed from easily extractable fractions to more stable fractions, little change was observed in residual fraction. Among the heavy metals investigated, the transformation rate was in the order $\mathrm{Pb}>\mathrm{Cu}>\mathrm{Zn} \gg \mathrm{Cd}$. No significant decrease of $\mathrm{Cd}$ was observed in the exchangeable fraction, indicating most of the anthropogenic $\mathrm{Cd}$ entered the mobile fraction and much longer time was needed for $\mathrm{Cd}$ to enter the immobilized fraction. Compared among the soils, changes of metal fractons in Janxi soil were much slower than in other two soils, which was mainly attributed to the low soil $\mathrm{pH}$. Soil with high OM content could bind more metals in organic matter fraction. Results of this work could be helpful for us to clarify the distribution of anthropogenic heavy metals in soil.

\section{Acknowledgement}

This work was funded by the National Natural Science Foundation of China (No. 20377049 and No.20237010).

\section{References}

Ahnstrom, Z.S., Parker, D.R., 1999. Development and assessment of a sequential extraction procedure for the fractionation of soil cadmium. Soil Sci. Soc. Am. J. 63, 1650-1658.

Alexander, M., 2000. Aging, bioavailability, and overestimation of risk from environmental pollutants. Environ. Sci. Technol. 34, 4259-4264.

Baker, D.E., 1990. Coopper. In: Alloway, B.J. (Ed.), Heavy Metals in Soils. Blackie \& Sons, London, UK, pp. 151-176.

Bataillard, P., Cambier, P., Picot, C., 2003. Short-term transformation of lead and cadmium compounds in soil after contamination. Eur. J. Soil Sci. 54, 365-376.

Berti, W.R., Jacobs, L.W., 1996. Chemistry and phytotoxicity of soil trace elements from repeated sewage sludge applications. J. Environ. Qual. 25, 1025-1032.

Carmen, E.M., Murray, B.M., 1999. Dissolved and labile concentration of $\mathrm{Cd}, \mathrm{Cu}, \mathrm{Pb}$, and $\mathrm{Zn}$ in aged ferrihydrite-organic matter system. Environ. Sci. Technol. 33, 740-750.

Carmen, E.M., Murray, B.M., 2001. $\mathrm{Cd}, \mathrm{Cu}, \mathrm{Pb}$, and $\mathrm{Zn}$ copreipitates in $\mathrm{Fe}$ oxide formed at different $\mathrm{pH}$ : aging effects on metal solubility and extractability by citrate. Environ. Toxicol. Chem. 20, 122-126. 
Chinese Environmental Protection Agency. 1995. Environmental quality standard for soils. GB 15618.

Davies, N.A., Hodson, M.E., Black, S., 2003. The influence of time on lead toxicity and bioaccumulation determined by the OECD earthworm toxicity test. Environ. Pollut. 121, 55-61.

Eillott, H.A., Liberati, M.R., Huang, C.P., 1986. Competitive adsorption of heavy metal by soils. J. Environ. Qual. 15, 214-219.

Forbes, E.A., Posner, A.M., Quirk, J.P., 1974. The specific adsorption of inorganic Hg (II) species and Co (III) complex ions on goethite. J. Colloid Interface Sci. 49, 403-409.

Forstner, U., 1995. Land contamination by metals-Global scope and magnitude of problem. In: Allen, H.G., Huang, C.P., Bailey, G.W., Bowen, A.R. (Eds.), Metal Speciation and Contamination of Soil. CRC Press, Boca Raton, FL, pp. 1-34.

Hendershot, W.H., Lalande, H., Duquette, M., 1993a. Soil reaction and exchangeable acidity. In: Carter, M.R. (Ed.), Soil Sampling and Methods of Analysis. Lewis Publisher, Boca Raton, FL, USA, pp. $141-165$.

Hendershot, W.H., Lalande, H., Duquette, M., 1993b. Ion exchange and exchangeable cations. In: Carter, M.R. (Ed.), Soil Sampling and Methods of Analysis. Lewis Publisher, Boca Raton, FL, USA, pp. 167-175.

Joner, E.J., Leyval, C., 2001. Time-course of heavy metal uptake in maize and clover as affected by root density and different mycorrhizal inoculation regimes. Biol. Fertil. Soils 33, 351-357.

Lim, T.T., Tay, J.H., Teh, C.I., 2002. Contaminant time effect on lead and cadmium fraction in a tropical coastal clay. J. Environ. Qual. 31, 806-812.

Ma, Y.B., Uren, N.C., 1998. Transformations of heavy metals added to soil-application of a new sequential extaction procedure. Geoderma 84, 157-168.

Ma, Y., Dickinson, N.M., Wong, M.H., 2002. Toxicity of Pb/Zn mine tailings to earthworm Pheretima and the effect of burrowing on metal availability. Biol. Fertil. Soils 36, 79-86.

McGrath, S.P., Cegarra, J., 1992. Chemical extractability of heavy metals during and after long-term application of sewage to soil. J. Soil Sci. 43, 313-321.

McLaughlin, M.J., 2001. Ageing of metals in soils changes bioavailability. Environ. Risk Assess. 4, 1-6.
Naidu, R., Bolan, N.S., Kookana, R.S., Tiller, K.G., 1994. Ionicstrength and $\mathrm{pH}$ effects on the sorption of cadmium and the surface charge of soils. Eur. J. Soil Sci. 45, 419-429.

Nelson, D.W., Sommers, L.E., 1996. Total cabon, organic carbon and organic matter. In: Sparks, D.L. (Ed.), Methods of Soil Analysis. Part 3. Chemical Methods. Soil Science Society of American, Madison, WI, USA, pp. 961-1010.

Pedersen, M.B., Kjar, C., Elmegaard, N., 2000. Toxicity and Bioaccumulation of copper to black bindweed (Fallopia convolvulus) in relation to bioavailability and the age of soil contamination. Arch. Environ. Contam. Toxicol. 39, 431-439.

Pueyo, M., Sastre, J., Hernández, E., Vidal, M., López-Sánchez, F., Rauret, G., 2003. Prediction of trace element mobility in contaminated soils by sequential extraction. J. Environ. Qual. 32, 2054-2066.

Quevauiller, P.H., Rauret, G., Griepink, B., 1993. Conclusions of the workshop: single and sequential extraction in sediments and soils. Int. J. Environ. Anal. Chem. 57, 135-150.

Ross, G.J., Wang, C., 1993. Extractable Al, Fe, Mn and Si. In: Carter, M.R. (Ed.), Soil Sampling and Methods of Analysis. Lewis Publisher, Boca Raton, FL, USA, pp. 239-246.

Samsoe-Petersen, L., Larsen, E.H., Larsen, P.B., Bruun, P., 2002. Uptake of trace elements and PAHs by fruit and vegetable from contaminated soils. Environ. Sci. Technol. 36, 3057-3063.

Sheldrick, B.H., Wang, C., 1993. Particle size distribution. In: Carter, M.R. (Ed.), Soil Sampling and Methods of Analysis. Lewis Publisher, Boca Raton, FL, USA, pp. 499-512.

Stalikas, C.D., Mantalovas, Ach., Pilidis, G.A., 1997. Multielement concentration in vegetable species grown in two typical agricultural areas of Greece. Sci. Total Environ. 206, 17-24.

Tessier, A., Campbell, P.G.C., Bisson, M., 1979. Sequential extraction procedure for the speciation of particulate trace metals. Anal. Chem. 51, 231-235.

Weng, L., Temminghoff, E.J., Lofts, S., Tipping, E., Van Riemsdijk, W.H., 2002. Complexation with dissolved organic matter and solubility control of heavy metals in a sandy soil. Environ. Sci. Technol. 36, 4804-4810.

Zhang, S.Z., Shan, X.Q., 1997. The determination of rare earth elements in soil by inductively coupled plasma mass spectrometry. At. Spectr. 18, 140-144. 